\title{
Long term follow-up of patients with chronic hepatitis $C$ treated with interferon alpha
}

\author{
Jane D Collier $\mathrm{MD}^{1}$, Paul A Adams $\mathrm{MD}^{2}$, Victor Feinman $\mathrm{MD}^{1}$, Cameron Ghent MD ${ }^{2}$, Helga Witt-Sullivan $\mathrm{MD}^{3}$, \\ Gerald Minuk MD ${ }^{4}$, Mel Krajden MD ${ }^{5}$, Jenny Heathcote MD ${ }^{1}$
}

JD Collier, PA Adams, V Feinman, et al. Long term follow-up of patients with chronic hepatitis $\mathrm{C}$ treated with interferon alpha. Can J Gastroenterol 2000;14(Suppl B):77B-80B. Interferon alpha (IFN ) treatment for chronic hepatitis $\mathrm{C}$ induces a sustained biochemical and virological response at six months after completing 24 weeks of therapy in approximately $10 \%$ of patients. The long term durability of this 'sustained' response is still controversial. The aim of this multicentre study was to assess the long term virological response in patients considered to have achieved a sustained biochemical response six months after completing IFN treatment. The majority (36 of 41) of the sustained responders identified had been treated for six months with IFN therapy. Twenty-nine of the 41 patients (70\%) had undetectable hepatitis $\mathrm{C}$ virus (HCV) RNA after a mean follow-up of 38 months after cessation of treatment (range six to 92 months). All but one of those 29 individuals had normal serum alanine aminotransferase (ALT) levels. Of the 16 patients (out of 41) who had been tested for HCV RNA six months after treatment, HCV RNA remained undetectable in 14 (88\%) at final follow-up. Serum ALT values in the 11 of 12 patients whose HCV RNA was positive at final follow-up were lower than pretreatment values, and in six cases were within the normal range. The long term sustained virological response in those considered a 'sustained responder' six months after receiving only six months of IFN is high. Measurement of ALT is an unreliable marker of sustained response to therapy.

Key Words: Hepatitis C; Interferon; Treatment

\section{Suivi à long terme des patients atteints d'hépatite $\mathrm{C}$ chronique et traités à l'interféron alpha}

RÉSUMÉ : Le traitement à l'interféron alpha (IFN) d'une durée de 24 semaines induit, chez environ $10 \%$ des patients atteints d'hépatite C chronique, une réaction biochimique et virologique soutenue au bout de six mois. Toutefois, la durabilité à long terme de cette réaction « soutenue » fait encore controverse. La présente étude multicentres a pour but d'évaluer la réaction virologique à long terme chez les patients chez qui une réaction biochimique soutenue a été observée six mois après avoir terminé un traitement à l'IFN. La majorité (36 sur 41) des sujets répondants avaient été traités à l'IFN pendant six mois. On n'a pu déceler la présence de l'ARN du virus de l'hépatite $\mathrm{C}(\mathrm{VHC})$ chez 29 des 41 patients (70 \%) après un suivi moyen de 38 mois après la fin du traitement (étendue de 6 à 92 mois). Les 29 patients, sauf un, présentaient une concentration normale d'alanine-aminotransférase (ALT) dans le sang. Des 16 patients (sur 41) qui avaient subi des tests de dépistage de l'ARN du VHC six mois après le traitement, 14 (88 \%) avaient des résultats négatifs à la dernière consultation de suivi. Les concentrations sériques d'ALT chez 11 des 12 patients dont les tests de dépistage de l'ARN du VHC s'étaient révélés positifs à la dernière consultation étaient inférieures aux valeurs initiales et, dans six cas, elles étaient dans les limites de la normale. La réaction virologique soutenue à long terme chez les patients qui se sont montrés de bons sujets répondants six mois après avoir été soumis à un traitement à l'IFN pendant six mois seulement est jugée importante. Quant à la mesure de l'ALT, elle est considérée comme un marqueur non fiable de réaction soutenue au traitement.

${ }^{1}$ Department of Medicine, Toronto Western Hospital, University Health Network, Toronto, Ontario; ${ }^{2}$ London Health Sciences Centre, London, Ontario; ${ }^{3}$ Mount Sinai Hospital, Toronto, Ontario; ${ }^{4}$ Hamilton General Hospital, Hamilton, Ontario; ${ }^{5}$ Health Sciences Centre, Winnipeg, Manitoba

Correspondence and reprints: Dr Jenny Heathcote, West Wing 4-828, The Toronto Western Hospital, University Health Network,

399 Bathurst Street, Toronto, Ontario M5T 2S8. Telephone 416-603-5914, fax 416-603-9195

Received for publication January 25, 2000. Accepted February 15, 2000 
Tnterferon alpha (IFN ) is a licensed and widely used treat1 ment for chronic hepatitis $\mathrm{C}$ (CHC). The aim of therapy is to normalize liver biochemistry and eradicate hepatitis $\mathrm{C}$ virus (HCV), and thus prevent the progression of hepatic fibrosis. Patients who respond to therapy are defined as those with normalized liver biochemistry, undetectable HCV RNA at treatment end or both. They may relapse after stopping therapy (1). A sustained response to treatment is defined as normalization of liver biochemistry and absence of detectable HCV RNA in serum six months after stopping treatment (2). Few studies have reported tonger term follow-up in sustained responders to assess whether normalization of liver biochemistry and of HCV RNA are maintained. Moreover, reports on the durability of thersustained virological response to six months of IFN are conflicting $(3-10)$.

The aim of this study was to assess the long term durability of the sustained biochemical and virological responses documented at six months after cessation of treatment with IFN in patients with CHC treated in Canada.

\section{PATIENTS AND METHODS}

Members of the Canadian Association for the Study of the Liver 'Hepatitis Group' were asked to identify adult CHC patients who had been treated with IFN and who were considered to be sustained responders six months after completing therapy, based on the lack of detection of HCV RNA in serum or normalization of liver biochemistry. Normalization of serum biochemistry alone was considered to be a sustained response in this study because universal and reliable HCV RNA assays were not available when some of the patients were treated. In addition, this was an acceptable endpoint to therapy in the early 1990 s.

Clinical details, including age, sex, source of hepatitis $\mathrm{C}$ infection, pretreatment serum aminotransaminase levels (alanine aminotransferase [ALT]), dose and length of IFN therapy, and ALT and quantitative HCV RNA values six months after completing therapy, were obtained for all patients from the clinical records.

All patients identified were asked to attend clinical reassessment, at which time serum was taken for measurement of serum ALT and HCV RNA. Serum samples for HCV RNA analysis were collected and stored at $-80 \mathrm{C}$ at each centre and transported at $-80 \mathrm{C}$ to one central laboratory for analysis.

The presence of HCV RNA in serum at final follow-up was determined by reverse transcriptase polymerase chain reaction using the Amplicor HCV (Roche, Basel, Switzerland) kit, whose lowest value of detection is 100 copies of viral RNA/mL serum.

\section{RESULTS}

Forty-one patients (27 male and 14 female) from five centres were identified as being sustained biochemical responders at six months after cessation of IFN therapy and returned for later reassessment. These five centres had treated over 600 $\mathrm{CHC}$ patients with IFN over the same time period. Six-
TABLE 1

Clinical characteristics of 41 sustained responders to interferon

\begin{tabular}{lc}
\hline Clinical features & Laboratory results \\
\hline Pretreatment ALT (median, range) & $155 \mathrm{IU} / \mathrm{L}$ (range 21-383) \\
Six months after treatment & $18 \mathrm{IU} / \mathrm{L}$ (range 9-77) \\
ALT & $16 / 16(100 \%)$ \\
HCV RNA negative in those tested & \\
Long term followw-up & 18 IU/L (range 8-335) \\
ALT & $32 / 38(85 \%)$ \\
ALT <40 IU/L (ie, normal) & $29 / 41(70 \%)$ \\
HCV RNA negative & $6 / 12(50 \%)$ \\
HCV RNA positive and normal ALT & $28 / 29(96 \%)$ \\
HCV RNA negative and normal ALT & \\
\hline
\end{tabular}

ALT Alanine aminotransferase; HCV Hepatitis C virus

teen of the 41 patients had been tested at the laboratory attached to their treatment centres and were reported as having undetectable HCV RNA in serum by the technique that was used in that laboratory at that time. All 16 patients had normal liver biochemistry at the time.

Mean age of the 41 patients was 44 years (range 22 to 69). The presumed sources of HCV infection were intravenous drug use $(n=16)$, blood products $(n=14)$ and needle stick injury $(n=3)$.

Thirty-six patients had been treated with subcutaneous IFN three times a week for six months, four patients for 48 weeks and one patient for 16 weeks. Two different types of IFN preparations were used, namely, IFN - 2b (Intron A, Schering, Madison, New Jersey) and IFN -1N (Wellferon, Burroughs-Wellcome, Research Triangle Park, North Carolina). Thirty-six patients had been treated with IFN $-2 \mathrm{~b}$ and five with IFN $-1 \mathrm{~N}$. The dose of IFN was $3 \mathrm{MU}$ throughout the treatment period for all but five patients; four patients had their dose reduced from $3 \mathrm{MU}$ to $1.5 \mathrm{MU}$, while one patient had the dose increased from $3 \mathrm{MU}$ to $5 \mathrm{MU}$. Two patients were cirrhotic before treatment.

Mean follow-up of these patients was 38 months (range six to 92) from six months after IFN treatment had been stopped. Their clinical profile is shown in Table 1.

Twenty-nine patients (70\%) had undetectable HCV RNA in serum after a mean follow-up of 38 months (range six to 92) (Table 1 ). Of those 16 patients known to have undetectable HCV RNA six months after therapy, in fourteen (88\%), HCV RNA remained undetectable (all tested by the same technique) at last follow-up (mean 33 months, range 11 to 55). Neither of the two patients who developed detectable HCV RNA in serum on follow-up had used intravenous drugs in the interim, which is a possible source of HCV reinfection.

The 12 patients (nine male and three female) who had detectable HCV RNA at the end of final follow-up had received a full 24 weeks of IFN therapy.

Twenty-eight of the 29 patients whose HCV RNA re- 


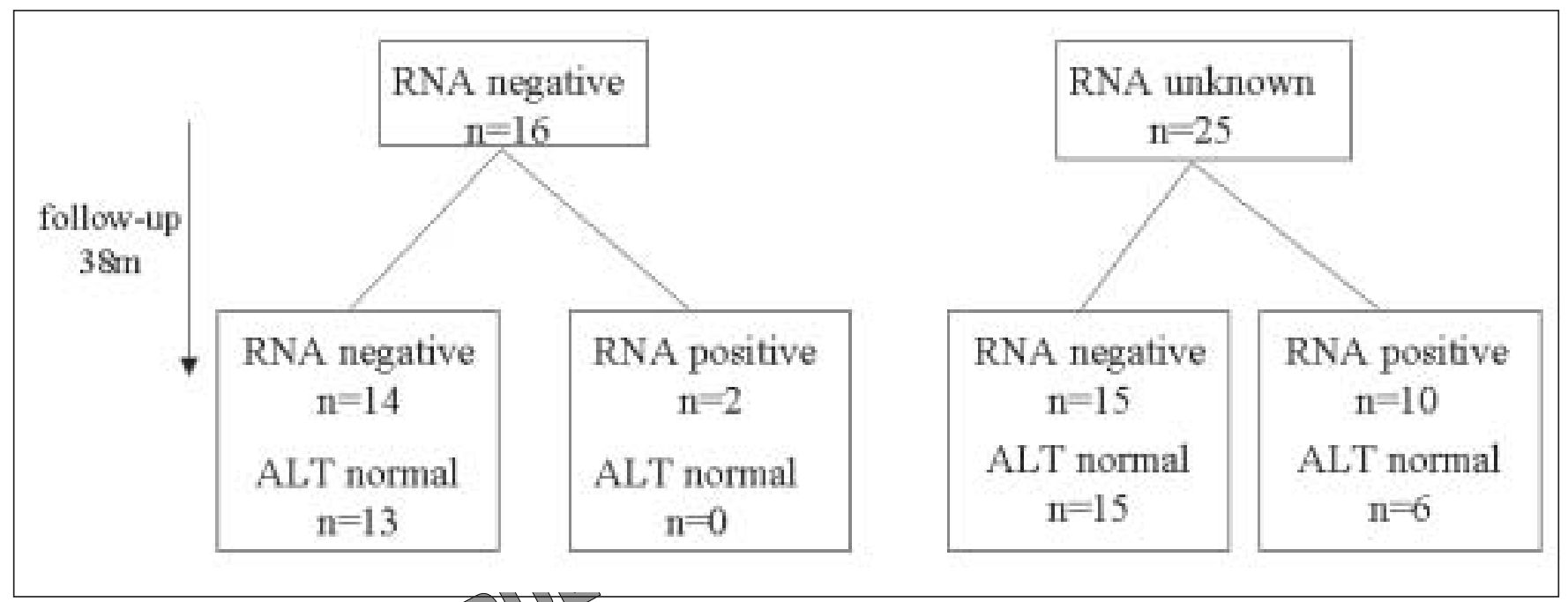

Figure 1) Alanine aminotransferase (ALT) Pevels in sustained responders, ie, patients $(n=41)$ who were considered to have achieved a sustained biological response six months after interferon therapy. RNA Hepatitis C virus RNA

mained undetectable at the end of final follow-up had normal liver biochemistry, whereas only six of the 12 who tested HCV RNA positive at final follow-up had normal liver biochemistry. In all but one patient who had a virological relapse, ALT levels were lower than pretreatment levels (Figure 1).

\section{DISCUSSION}

This study shows that a long term virological response to six months of IFN therapy for $\mathrm{CHC}$ is durable in at least $70 \%$ of patients. Serum HCV RNA status was unknown in more than half of this study's patients who, based simply on ALT normalization, were considered to have a sustained response to IFN therapy six months after treatment stopped. These findings are dissimilar to those of a smaller study by Vento et al (3), in which, of 13 patients who had undetectable HCV RNA 12 months after completion of six months of therapy, only four (25\%) still had undetectable HCV RNA three years after treatment; by seven years, all tested positive for HCV RNA.

In contrast, results from other studies that included patients treated for six or 12 months with IFN have shown long term response rates similar to ours, ie, durable virological response in $70 \%$ to $96 \%$ of sustained responders (4-10). Two of these studies were larger than our study and they included more patients treated with INF for 12 months $(4,5)$. Chemello et al (4) reported that of 107 patients with a biochemical response 12 months after completing treatment with IFN, serum HCV RNA remained undetectable in 80 (74\%) after a mean follow-up of 35 months.

Similar to what was found in our study, patients who were known to have undetectable HCV RNA six months after cessation of IFN therapy were more likely to have a durable response than those considered a responder based only on normalization of liver biochemistry. All 80 patients in the study by Chemello and colleagues (4) with a prolonged virological response had undetectable HCV RNA 12 months after cessation of therapy. Hagiwara et al (6) reported that of 37 patients who had a sustained biochemical response at six months and who were followed for 26 to 40 months after treatment, 28 (75\%) had undetectable HCV RNA at the end of follow-up.

In that study (6), the lack of detectable HCV RNA in serum six months after treatment cessation also predicted a good long term virological response. Thus, normalization of liver biochemistry six months following treatment with IFN does not imply a virological response (5). However, a 90\% sustained long term response rate has been reported in patients who had normal liver biochemistry 12 months after cessation of IFN therapy (8). Marcellin et al (7) reported that of 80 patients who had undetectable HCV RNA six months after stopping IFN treatment, 72 (90\%) had undetectable HCV RNA in serum after a mean follow-up of four years.

Unlike the report made by Vento and colleagues (3), our study suggests that a sustained virological response observed six months after cessation of IFN therapy is durable over the long term in most patients. Moreover, Lau et al (9) has shown, in a small study, that sustained undetectability of HCV RNA in serum, six to 13 years after completing therapy, correlates with loss of HCV RNA from liver tissue.

Although the majority of patients who wereHCV RNAnegative at the end of follow-up had normal liver biochemistry, one patient still had an eleyared ALT level. Abnormal ALT after IFN treatment may be due to coexistent liver disease, such as hepatic steatosis secondary to obesity, drug toxicity, or other causes. ALT levels cannot, therefore, be used as a reliable surrogate marker of a long term sustained response to antiviral therapy.

Currently it cannot be accurately determined which patients will respond to treatment, with loss of detectable HCV RNA that will be sustained after withdrawal of therapy. It has been suggested that the lack of detectable HCV RNA in the liver at the end of a six-month course of 
therapy may be a better predictor of a sustained virological response than testing serum after completing therapy (11-15). But invasive liver biopsy and examination of the tissue for HCV RNA is not routinely conducted after cessation of therapy. The poor correlation between serum ALT values and loss of detectable HCV RNA in serum is demonstrated in this study (Figure 1). Our results suggest that testing for HCV RNA in serum at six to 12 months after cessation of IFN therapy accurately predicts long term final outcome in $88 \%$ of patients. The long term follow-up data available on the durability of a sustained response to the current standard of care, that is, the combination of IFN and ribavirin, appear to be similar to results from IFNS monotherapy (16).

\section{REFERENCES}

1. Poynard T, Leroy V, Cohard M, et al. Meta-analysis of interferon randomized trial in the treatment of viral hepatitis C: effect of dose and duration. Hepatology 1996;24:778-89.

2. Lindsay KL. Therapy of hepatitis C: overview. Hepatology 1997;26(Suppl 1):71S-7S.

3. Vento S, Concia E, Ferraro T. Lack of sustained efficacy of interferon in patients with chronic hepatitis C. N Engl J Med 1996;334:1479-80.

4. Chemello L, Cavalletto L, Casarin C, et al. Persistent hepatitis C viraemia predicts late response to interferon alpha in chronic hepatitis C. Ann Intern Med 1996;124:1058-60.

5. Manesis EK, Papaioannou C, Gioustozi A, Kafiri G, Koskinas J, Hadziyannis SJ. Biochemical and virological outcome of patients with chronic hepatitis $C$ treated with interferon alfa-2b for 6 or
12 months: a 4 year follow-up of 211 patients. Hepatology 1997;26:734-9.

6. Hagiwara H, Hayashi N, Kasahara A, et al. Long-term biochemical and virological response to natural interferon- in patients with chronic hepatitis C. Dig Dis Sci 1996;41:1001-7.

7. Marcellin P, Boyer N, Gervais A, et al. Long-term histological improvement and loss of detectable intrahepatic HCV RNA in patients with chronic hepatitis $\mathrm{C}$ and sustained response to interferon alpha therapy. Ann Intern Med 1997;127:875-81.

8. Gamma C, Di Marco V, Iacono OL, et al. Long-term course of interferon-treated chronic hepatitis C. J Hepatol 1998;8:531-7. Lau T-Y, Kleiner DE, Ghany MC, et al. 10-year follow-up after interferon-alpha therapy for chronic hepatitis C. Hepatology 1998:28:1121-7.

10. Sim H,Yim C, Krajden M, et al. Durability of serological remission in chronic hepatitis $\mathrm{C}$ treated with interferon-alpha-2B. Am J Gastroenterol 1998;93:39-43.

11. Gurakar A, Fagiuoli S, Faruki H, et al. Utility of hepatitis C virus RNA determinations in hepatic tissue as an endpoint for interferon treatment of chronic hepatitis C. Hepatology 1995;22:1109-12.

12. Karino Y, Toyota J, Sugawara M, et al. Early loss of serum hepatitis $\mathrm{C}$ virus RNA can predict a sustained response to interferon therapy in patients with chronic hepatitis C. Am J Gastroenterol 1997;92:61-5.

13. Kakumu S, Aiyama T, Okumura A, Iwata K, Ishikawa T, Yoshioka K. Earlier loss of hepatitis $\mathrm{C}$ virus RNA in interferon therapy can predict a longterm response in chronic hepatitis C. J Gastroenterol Hepatol 1997;12:468-72.

14. Toyoda H, Kumada T, Nakano S, et al. Significance of early measurement of serum hepatitis $\mathrm{C}$ virus RNA in predicting response to interferon therapy in patients with chronic hepatitis C. Eur J Gastroenterol Hepatol 1997;9:245-9.

15. Ampurdanes S, Olmedo E, Maluenda MD, et al. Permanent response to alpha-interferon therapy in chronic hepatitis $\mathrm{C}$ is preceded by rapid clearance of HCV RNA from serum. J Hepatol 1996;25:827-32. 


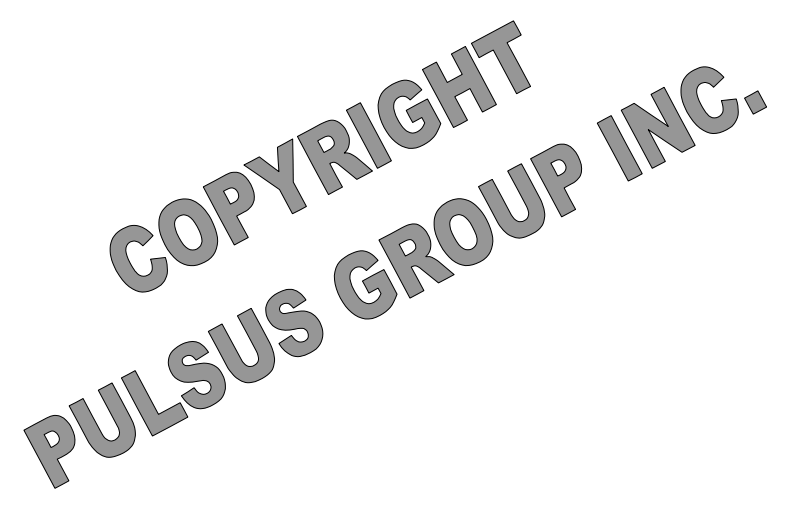




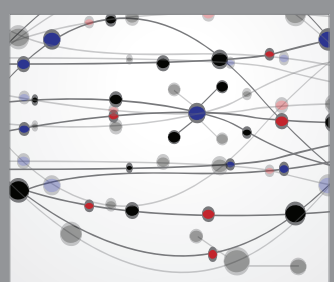

The Scientific World Journal
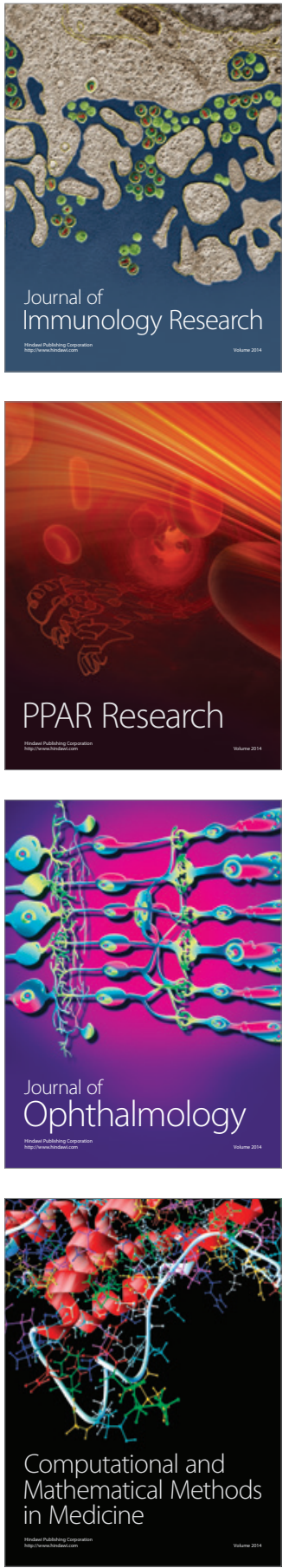

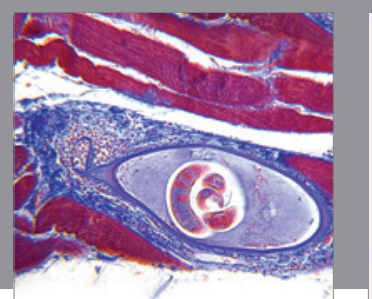

Gastroenterology Research and Practice

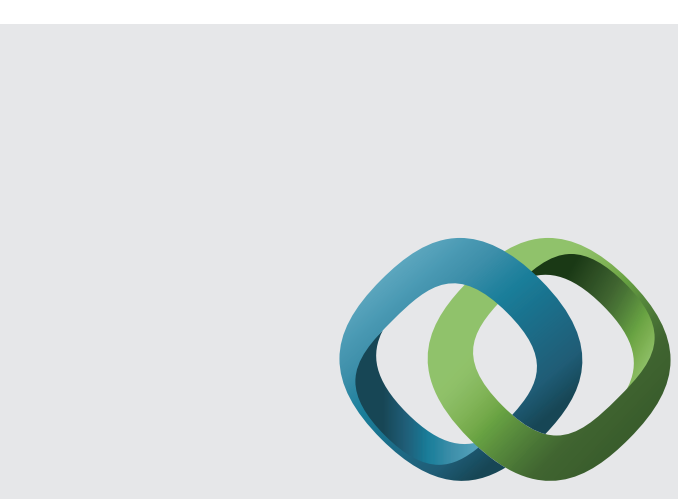

\section{Hindawi}

Submit your manuscripts at

http://www.hindawi.com
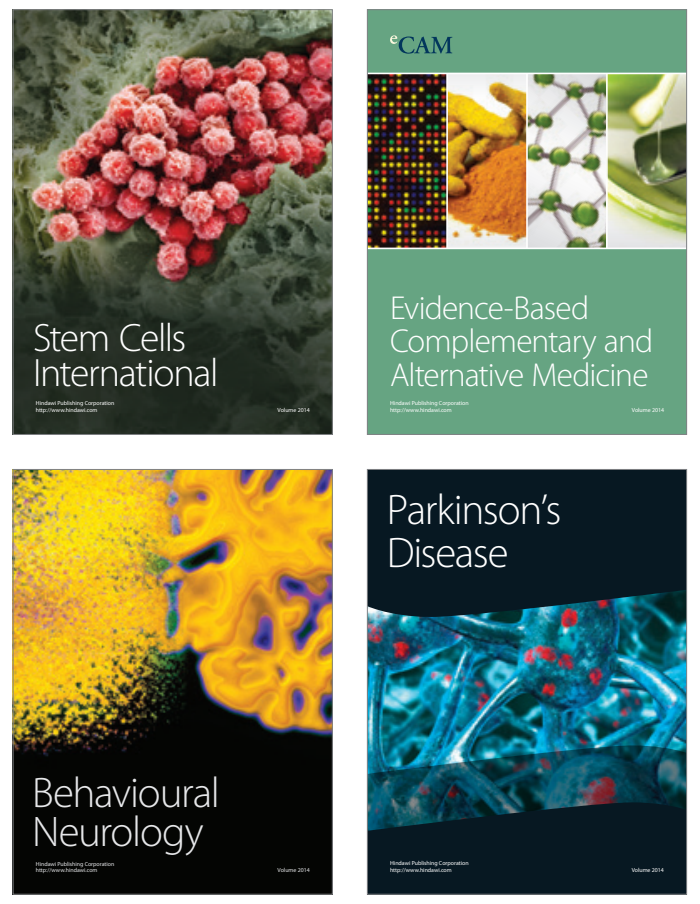
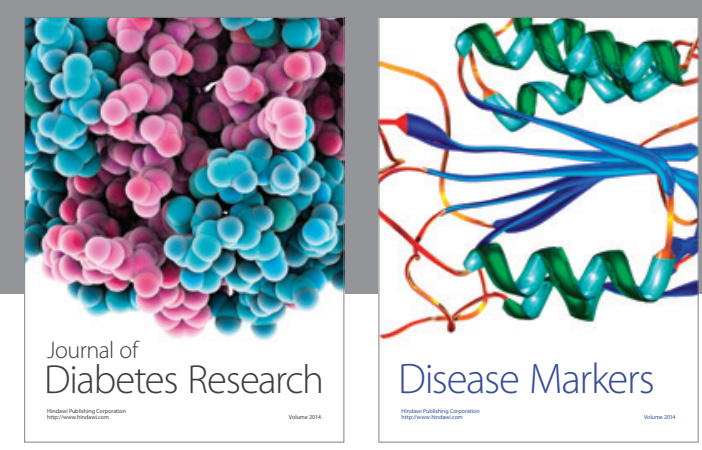

Disease Markers
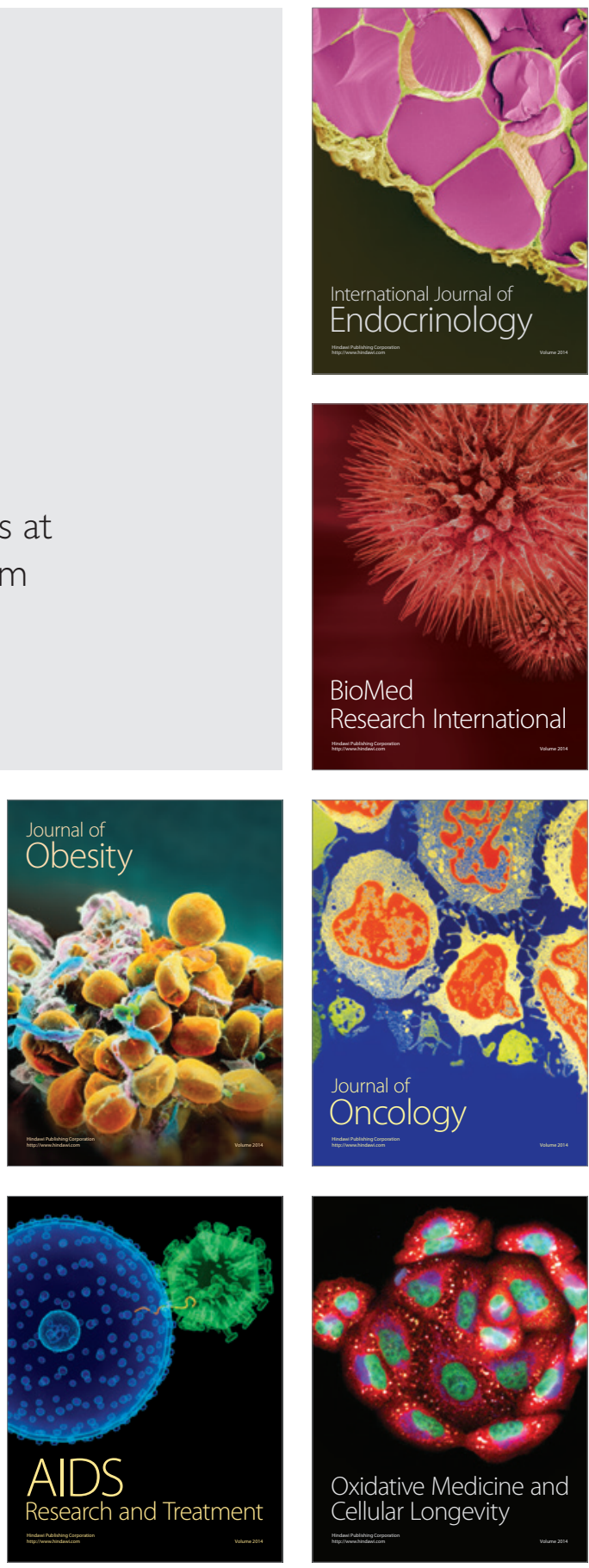